\title{
The Development of the
} Water-Energy-Food Nexus as a Framework for Achieving Resource Security: A Review

\author{
Gareth B. Simpson ${ }^{1,2 *}$ and Graham P. W. Jewitt ${ }^{2 \dagger}$ \\ ${ }^{1}$ Jones and Wagener (Pty) Ltd., Centurion, South Africa, ${ }^{2}$ Centre for Water Resources Research, College of Agriculture, \\ Engineering and Science, University of KwaZulu-Natal, Pietermaritzburg, South Africa
}

OPEN ACCESS

Edited by:

Richard George Lawford

Morgan State University, United States

Reviewed by:

Nitin Kaushal,

World Wide Fund for Nature, India

Xueliang Cai,

IHE Delft Institute for Water Education,

Netherlands

*Correspondence:

Gareth B. Simpson

simpson@jaws.co.za

†Present Address:

Graham P. W. Jewitt,

IHE Delft Institute for Water Education,

Delft, Netherlands

Specialty section:

This article was submitted to

Freshwater Science,

a section of the journal

Frontiers in Environmental Science

Received: 02 September 2018

Accepted: 15 January 2019

Published: 08 February 2019

Citation:

Simpson GB and Jewitt GPW (2019)

The Development of the

Water-Energy-Food Nexus as a

Framework for Achieving Resource

Security: A Review.

Front. Environ. Sci. 7:8.

doi: 10.3389/fenvs.2019.00008
This paper presents a study of the evolution of the water-energy-food (WEF) nexus since its rise to prominence in policy and development discourses in 2011. Drawing from an extensive review of published literature, the paper presents various interpretations of the concept while also considering the novelty of the WEF nexus. The challenge of integrating and optimising the components of this multi-centric nexus is examined, with four case studies being presented. Various criticisms levelled at the WEF nexus, such as the neglect of livelihoods and the environment in assessments, are noted, together with governance considerations associated with this framework. Finally, the potential of the WEF nexus to contribute to the achievement of the Sustainable Development Goals is reviewed.

Keywords: water-energy-food nexus, framework, resource security, governance, sustainability development goals

\section{INTRODUCTION}

Meadows et al. (1972) warned almost half a century ago, "If the present growth trends in world population, industrialisation, pollution, food production, and resource depletion continue unchanged, the limits to growth on this planet will be reached sometime within the next one hundred years." Some three decades later they stated that "the human economy is exceeding important limits now and that this overshoot will intensify greatly over the coming decades" (Meadows et al., 2004). Just a few years after this latter statement, average world food prices increased significantly, leaving a large portion of the global population unable to afford their basic nutritional needs (Mohtar and Daher, 2012). These increased food prices are an indication of growing natural resource scarcity (Ringler et al., 2013).

The finite and indispensable nature of freshwater also came to the fore during the first decade of the twenty-first century. In their 2011 publication, Water Security: The Water-Food-Energy-Climate Nexus, the World Economic Forum highlighted that in many locations around the globe, water has been consistently under-priced, groundwater has been depleted, and that unlike energy, water has no substitutes or alternatives (WEF, 2011). However, Sachs (2015) states that "Of all of the problems of reconciling growth with planetary boundaries, probably none is more urgent and yet more complicated than the challenge of the world's energy system."

Projections are that the global demand for resources is going to escalate on this "hot, hungry, crowded, and fast evaporating planet" (WEF, 2011). The NIC (2012) estimate that the growth in demand for food, water and energy by 2030 will be 35,40 , and 50 percent, respectively. This is due to an increasing population, urbanisation, and an additional three billion middle-class people by 2030 (WWF and SABMiller, 2014). There is also a dire need to enhance the livelihoods of the "bottom billion" who are undernourished, without access to electricity and clean water (IRENA, 2015). 
Speaking on World Water Day in March 2011, the then Secretary-General of the United Nations, Ban-Ki Moon, noted that the interconnects between water, energy and food are among the greatest challenges that mankind faces. In November of that year, the Bonn2011 Conference: Water Energy and Food Security Nexus-Solutions for the Green Economy was convened. That meeting served as a catalyst for wider interest in the waterenergy-food (WEF) nexus amongst academics, policy makers, national and international development agencies and donor countries. While some authors suggest that the WEF nexus has traits of a "nirvana concept," others have identified several shortcomings in nexus thinking, labelling it as an immature approach (Allouche et al., 2015).

In this review, search terms related to the paper's title were entered into the EBSCOhost, Web of Science, Science Direct, and Wiley Online databases. These searches yielded 111, 212, 135, and 53 results respectively, i.e., a total of 511 academic papers. After removing duplicates (104), articles were excluded based on a review of their titles (284) and abstracts (38). A further 32 articles were subsequently excluded during a full screening of the texts, yielding 53 academic articles that have contributed to this literature review. Fourteen grey literature sources that were identified during the review of the academic articles were subsequently included in the literature review process. This methodology was followed to remove bias, as far as possible, from the selection of academic and grey literature for inclusion in the compilation of this manuscript.

This paper initially examines what is understood by the term "WEF nexus." It continues to provide an analysis of whether the WEF nexus is a unique approach, or if it is simply a repackaging of an existing framework (even though a "repackaging" would not necessarily imply irrelevance). The challenge of integrating and optimising these three resource sectors, together with their trade-offs and synergies, is subsequently presented together with four case studies. Thereafter, one of the key criticisms levelled at the WEF nexus is considered, namely, whether the resource security goal of the WEF nexus, which the global economic community is seen to be driving, accommodates the environment and livelihoods. Finally, the possible benefits of the WEF nexus approach in terms of policy development and governance are reviewed.

\section{WHAT IS THE WEF NEXUS?}

The word nexus means "to connect" (De Laurentiis et al., 2016). This word conveys the interactions between two or more elements, be they dependencies or interdependencies. The WEF nexus is, therefore, the study of the connections between these three resource sectors, together with the synergies, conflicts and trade-offs that arise from how they are managed, i.e., water for food and food for water, energy for water and water for energy, and food for energy and energy for food.

Some authors argue that there is little agreement on the WEF nexus' precise meaning, contending that there are many competing (and often overlapping) conceptions (Benson et al., 2015; Al-Saidi and Elagib, 2017). Others suggest that the term can be viewed as a buzzword, i.e., a word that gains prominence due to "a combination of ambiguous meaning and strong normative resonance" (Cairns and Krzywoszynska, 2016). Gain et al. (2015) report that many developing countries are not even aware of the WEF nexus. Cairns and Krzywoszynska (2016) found that within natural resource discussions in the United Kingdom, the understanding and usage of the term WEF nexus is "plural, fragmented, and ambiguous." Their concern is that the broad use of the term could trivialise its importance.

Wichelns (2017) states that the selection of water, energy and food as the principal components of a nexus framework for guiding research and policy, although initially appealing, is somewhat arbitrary. Liu et al. (2018) note that while the energy sector speaks of the energy-water-food (EWF) nexus, hydrologists and water engineers call it the water-energyfood (WEF) nexus, while those in the agricultural fraternity use the term, the food-energy-water (FEW) nexus. Based on this variance in terminology, it is evident that the conceptual approach to the WEF nexus is generally dependent upon the perspective of the particular researcher or policy-maker (Bazilian et al., 2011). Allouche et al. (2015) agree that the term can mean different things to different people, arguing that while some consider the WEF nexus scope to be too narrow, excluding for example climate change and the environment, other authors view it as being relatively broad and link it to the green economy, poverty reduction and global resource security (Pandey and Shrestha, 2017).

The World Economic Forum's primary area of concern regarding the WEF nexus was initially water security, hence it is termed by some as the WEF security nexus. Different groupings who have embraced the WEF nexus approach have contrasting foci, e.g., sustainability, the green economy, tradeoffs, livelihoods, climate, optimisation, modelling, or scarcity. Pahl-Wostl (2017) explains that the WEF nexus was strongly focused on resource security during the first four years after the Bonn2011 Conference, but since then the concept's use has broadened to address interdependencies and integration to achieve the sustainable management of resources.

While there is disagreement on what the term "nexus" means, this is not the first term that the academic and development community has struggled to define. Meadows et al. (2004) note that sixteen years after the Brundtland Commission mainstreamed the concept of sustainability (Brundtland, 1987) the global society was still trying to agree on what the term meant.

The debate regarding the nexus' precise meaning and application indicates that it is still an evolving concept (Allouche et al., 2015; Pandey and Shrestha, 2017). While there are differing interpretations of this framework, de Loe and Patterson (2017) suggest that what is paramount is "nexus thinking," as opposed to a specific strict definition of the WEF nexus.

\section{IS THE WEF NEXUS CONCEPT NOVEL?}

Many authors question whether the WEF nexus approach is novel (Allouche et al., 2015; Benson et al., 2015; Muller, 2015; Wichelns, 2017). The FAO (2014), for example, query whether 
the concept is just the "same old wine in new bottles," or if it contributes something new to the sustainable development discourse. It is also questioned whether the nexus is complete with only three sectors being represented. Climate change, the environment, land, governance, urbanisation, waste, or livelihoods are some of the other components that could be, and are, assessed together with the trio of sectors that make up the WEF nexus. To this end, Wichelns (2017) queries the selection of the three resource sectors in the WEF nexus and the widespread recognition that the concept is receiving, noting that it is not yet an agreed and tested framework.

Benson et al. (2015) argue that many of the ideas presented in the nexus philosophy already appeared in other strategies which entered policy discourses in the 1990s. When sustainable development was first proposed, it was stated that population growth, food security, energy, the environment, and urban development "are connected and cannot be treated in isolation one from another" (Brundtland, 1987).

Muller (2015) explains that the 1977 United Nations conference proceedings reveal that the world at that time was fully cognisant of the interdependencies between water, food and energy. This is evident when reading the seminal work, The Limits to Growth, wherein it is highlighted that the five major areas of global concern identified "are all interconnected in many ways" (Meadows et al., 1972).

Cai et al. (2018) note that since the Harvard Water Program in the early 1960s there has been a drive to address water research utilising an interdisciplinary approach. Wichelns (2017) reports that the need for greater integration of research and policy discourse across sectors and regions was expressed in international meetings as early as the late 1940s. In terms of the interconnected nature of all subjects of study in the biosphere, Muir (1911) stated that "When we try to pick out anything by itself, we find it hitched to everything else in the universe." There is truly "nothing new under the sun."

If the WEF nexus is not novel, then why has there been so much interest in the approach from organisations such as the World Economic Forum, the World Wide Fund for Nature, the United Nations and global companies like the Coca-Cola Company and SABMiller? Wichelns (2017) suggests that much of the interest in the nexus is as a result of the concern of the impact of climate change on water, energy and food security. Rasul and Sharma (2016) are in agreement, noting that all three resource sectors are influenced by climate change and that they, in turn, each contribute to that impact as a result of their discharges and/or emissions. Pandey and Shrestha (2017) contend that the concept of the WEF nexus has gained prominence as a contemporary way to understand and approach sustainable development.

In terms of the governance of water, one framework that was formalised in the early 1990s was Integrated Water Resources Management (IWRM). IWRM was initially embraced as the silver bullet of sustainable development because of its integrated analysis of sectors and resources (Kurian, 2017). The United Nations included IWRM as a component of the Millennium Development Goals (MDGs) (Benson et al., 2015). Bogardi et al. (2012) however argue that IWRM on its own is insufficient.
Benson et al. (2015) suggest that the WEF nexus framework exhibits some innovative elements, such as holistically integrating different policy sectors, and contend that it could be highly complementary to IWRM.

While several authors argue that the interdisciplinary nature of the approach is not new, the primary reason for promoting the WEF nexus approach above that of IWRM is that it is multicentric, with each sector being treated with equal importance, while IWRM is water-centric (Allouche et al., 2015; Benson et al., 2015; Abdullaev and Rakhmatullaev, 2016; Gallagher et al., 2016; Al-Saidi and Elagib, 2017; Liu et al., 2017; Owen et al., 2018). Cai et al. (2018) suggest that the WEF nexus may be accepted by a broader set of stakeholders than IWRM, especially those within the agricultural and energy sectors.

\section{INTEGRATING AND OPTIMISING THE WEF NEXUS}

Some critics of the WEF nexus argue that the analysis of one resource sector is sufficiently complex, suggesting that integrating multiple resource sectors simultaneously poses an appreciable challenge (de Loe and Patterson, 2017). Wichelns (2017) concurs, contending that given the lack of success in implementing Integrated Natural Resource Management (INRM) and IWRM in practice, another call for integration should be questioned. It has however been suggested that the critique of IWRM is wellfounded because it is perceived to underestimate the importance of administrative boundaries, with its focus being hydrological catchments (Kurian, 2017). de Loe and Patterson (2017) contend that IWRM has failed to achieve the goals for which it was intended. Abdullaev and Rakhmatullaev (2016) agree, stating that the active promotion of a nexus approach could assist in solving the IWRM's "water box problem." Belinskij (2015) argues for utilising a nexus approach since it removes the institutional "silos" that are so prevalent in governance and policy circles.

Leck et al. (2015) warn that the multi-sector goal of the WEF nexus, with its associated trade-offs and interdependencies, could result in its downfall. They warn that although the nexus concept is attractive, it is challenging to implement. Yet, Wicaksono et al. (2017) argue that the fundamental notion of the WEF nexus has already been adopted in some regions and countries, although not necessarily under the banner of this framework itself. Daher et al. (2017), while acknowledging the complexity of modelling the nexus (i.e., computer-based modelling), emphasise that there is no one-size-fits-all model to address WEF-related issues. They continue to describe how localising and contextualising a nexus assessment will be vital to addressing trade-offs. An example of localising and contextualising the WEF nexus at a sub-national level is provided in "Case Study 1".

Another challenge for WEF nexus analyses stems from globalisation. The liberalisation of trade has meant that the interactions between water, energy, and food are very complex since materials and products are continually crossing international borders (Owen et al., 2018). Water moves between countries as an embedded component of food and other products as "virtual water" (Bogardi et al., 2012). Closely linked to 


\begin{abstract}
Case Study 1:
The province of Mpumalanga in South Africa is the energy hub of the country. It is the source of significant coal resources and most of the fossil-fuelbased power stations that burn much of the coal. However, "South Africa has only $1.5 \%$ high potential arable soils (soils best suited for cash crop production), and $46.4 \%$ of this total area is in Mpumalanga" (BFAP, 2012). The development of coal mines, especially opencast operations, is continually reducing the area of high potential arable soils in South Africa (Simpson and Berchner, 2017). The continued pursuit of fossil-fuel based energy dependency in South Africa is, therefore, threatening food security. It is also negatively impacting upon air pollution (Greenpeace, 2018) and water quality (McCarthy, 2011). A WEF nexus-based assessment of South Africa indicates that policy related to the accelerated implementation of renewable energy generation must be adopted if the nation is to move toward a low-carbon, sustainable future.
\end{abstract}

the concept of virtual water is large-scale land acquisitions (LSLAs). In order to secure their essential resources, several developed countries (e.g., the United Kingdom and Italy) have pursued LSLAs, predominantly in developing countries, such as Guinea, Sierra Leone, and Mozambique (Siciliano et al., 2017). These LSLAs are ultimately concerned with gaining access to land and water for energy (i.e., biofuel) and food production. What is concerning is that malnutrition and economic water scarcity often exist in countries where LSLAs have occurred. In so doing the wealthier nations, in seeking to secure resources for themselves through LSLAs, reinforce the concerns of several authors regarding the securitisation agenda, i.e., that livelihoods of the poorer members of the global society are neglected in the developed world's pursuit of macro-scale resource security.

Quantifying the movement of virtual water between nations and regions is not the only challenge. Liu et al. (2017) suggest that the scientific challenge associated with the WEF nexus is primarily related to the myriad of data required to undertake the necessary analyses. Further, water, energy and food are measured in different manners, with each having their own units of measurement.

In addition to the data and integration challenges associated with the WEF nexus, there are multiple spatial and temporal scales within which this framework can be viewed. These scales influence each other (Garcia and You, 2016). In terms of the spatial extent, a WEF nexus assessment could be undertaken at a city, basin, national, regional, or global level. An example of a regional assessment is provided in "Case Study 2." Although Muller (2015) questions the novelty and completeness of the WEF nexus, it is argued that what the WEF security framework does do is to move the spotlight of water resources management "from watersheds to problem-sheds, from what society should do for water to what water can do for society."

Regarding the temporal nature of a WEF nexus study, an instantaneous snapshot of the status of a WEF system could be developed. Alternatively, the metabolism of a city could be provided over a period, such as a month or a year. A further challenge related to seeking to optimise the WEF nexus is that a researcher could focus on human needs, trying to attain

\section{Case Study 2}

With less than $5 \%$ of the world's land area, South Asia has to feed about onequarter of the global population (Rasul, 2016). To ensure food self-sufficiency, many South Asian countries have adopted policies that encourage farmers to increase food production, including the provision of subsidies for irrigation, energy, and fertilisers, and the guarantee of minimum prices for wheat and rice. This has resulted in an alarming rate of decline in groundwater levels since these subsidies have discouraged farmers from being efficient in their use of both water and energy. "Thus, a nexus 'no-brainer' is to review and identify candidates for the phase-out of subsidies on water, energy, land and food" (Ringler et al., 2013). Current water and energy charges are often too low to affect behaviour. The irony is that by providing water and energy for agriculture at a low cost, food security can itself ultimately be threatened.

an equilibrium, while neglecting environmental considerations, climate change or poverty alleviation.

Although much of the literature associated with the WEF nexus is dismissive of the "silo" approach to resource management, some argue that "the baby should not be thrown out with the bathwater." Wichelns (2017), for example, notes that there are times when an in-depth study within a particular discipline is required. Artioli et al. (2017), however, suggest that the momentum that the WEF nexus approach has attained within policy circles will be difficult to curtail.

\section{DOES THE WEF NEXUS ADDRESS RESOURCE SECURITY FOR ALL?}

Gupta (2017) contends that the WEF nexus is a security nexus for societal well-being. Indeed, Hoff (2011) in the background paper for the Bonn2011 Conference highlighted the "need to secure local livelihoods and the non-negotiable human rights to water and food." Wichelns (2017) however, argues that livelihoods are often omitted in WEF nexus analyses, even though the poorest members of the global society are often impacted most severely by the policy changes that emanate from a nexus approach. This is because the achievement of food security at the household, city, provincial, or country level is more complex than balancing supply and demand on a macro-scale (Grafton et al., 2016).

There is an emerging resource security focus utilising the WEF nexus as the guiding framework which is motivated by the possibility that economic growth will soon be constrained by shortages of one or more of the sectors constituting this nexus (Salam et al., 2017). There has also been an increasing focus on water security within the private sector during the past decade (Leck et al., 2015), and Green et al. (2017) note that the private sector is often influential in decisions appertaining to the provision and management of water, energy, and food.

Spiegelberg et al. (2017) agree that there is a general economic motivation behind the WEF nexus, explaining that the literature focuses primarily on three fields of global growth, namely, the increase in population, urbanisation, and the burgeoning middle class in developing countries with their "Western" consumer demands. Biggs et al. (2015) go further, stating categorically that nexus frameworks have failed to 
adequately incorporate livelihoods into their thinking, i.e., resource security for all. They suggest that this is counterintuitive since supporting livelihoods is implicit in the attainment of sustainable development. This relegation of livelihoods is in conflict with one of the three guiding principles of the WEF nexus philosophy highlighted at the Bonn2011 Conference, which is that people and their basic human rights must be the basis of this approach (Salam et al., 2017).

Leese and Meisch (2015) suggest that whereas sustainability has historically focused on distributional justice, it is now often viewed in terms of resource security. The risks associated with the unavailability of water, energy, and food have become a global concern (WEF, 2011; NIC, 2012). Leese and Meisch (2015) argue that the WEF nexus' focus on securitisation, i.e., the security agenda centered on the risk of non-supply, is one that is driven by economic considerations, not the challenges related to livelihoods, which has traditionally been within the ambit of sustainable development. Further, they contend that the sustainability focus on equitable access to resources is being usurped by the threat to global productivity and living standards.

In summary, the concern of these authors is that sustainability is being securitised, i.e., one component of sustainable development is being focused upon to the detriment of the other components. The belief is that the World Economic Forum is prioritising this agenda and that improved macro-scale food security will not ipso facto result in a reduction in the prevalence of undernourishment, i.e., Sustainable Development Goal (SDG) 2. Nor will improved water security at a national level necessarily lead to an increase in the levels of access to clean water and improved sanitation facilities, i.e., SDG 6. Biggs et al. (2015) explain that "security" should not refer only to the availability of resources, but also to universal access to them.

Salam et al. (2017), however, contend that the amalgamation of water, energy, and food in a nexus framework to increase resource efficiency can be considered as a necessary way to achieve the SDGs. Rasul and Sharma (2016) agree, stating that the nexus outlook can assist in aligning the SDGs with planetary boundaries. The SDGs provide a basis upon which the WEF nexus can be developed (Gallagher et al., 2016).

To sustainably achieve resource security for all, the integrity of ecosystem services and the associated resource base must be maintained while access to resources is expanded and consolidated. This is presented schematically in Figure 1, where all the SDGs are directly or indirectly connected to food. Rockström and Sukhdev (2016), who developed this illustration, propose that the goals for eradicating poverty (SDG 1) and hunger (SDG 2) require gender equality (SDG 5), adequate jobs (SDG 8), and a decrease in inequality (SDG 10).

Ringler et al. (2013) explain that assessments utilising a nexus approach must consider both livelihoods and the environment. de Grenade et al. (2016) comment that while the "nexus" has various key strengths, it fails to adequately acknowledge the environment as its irreplaceable foundation. Planetary boundaries are however being threatened (Rockstrom et al., 2009) as predicted by Meadows et al. (1972). The challenge is to develop policies that support the sustainability of water, energy, and food resources, while simultaneously providing access to these resources for all levels of society. Achieving sustainability necessarily requires that the protection of the environment be prioritised.

\section{GOVERNANCE CONSIDERATIONS ASSOCIATED WITH THE WEF NEXUS}

It could be said, "let us eat, drink, spend, extract and pollute, and be as merry as we can, and let posterity worry about the spaceship earth" (Boulding, 1966). A philosophy such as this would fly in the face of sustainable development, which calls us to ensure that the needs of the current generation are not met in a manner that compromises the ability of our children to meet their own needs (Brundtland, 1987). Achieving a profound goal such as this requires a practical, holistic framework, and strong governance. Al-Saidi and Elagib (2017) suggest that a governance focus is a missing ingredient in the nexus debate.

Governance of the WEF nexus includes a wide range of private and public systems that manage the supply and demand of water, energy and food (Pahl-Wostl, 2017). Providing access to improved water sources, sanitation facilities and electrification is viewed by most citizens as a barometer of good governance and is reflected in both the Millenium Development Goals (MDGs) and SDGs. Benson et al. (2017) argue that effective governance for the nexus occurs when the integration of resource sectors is actively pursued, such that synergies between water availability, energy generation and food production are enhanced, while trade-offs are managed, and potential conflicts are averted. An example of the management of a WEF nexus trade-off, and the dissipation of a potential international conflict, is presented in "Case Study 3." Although the WEF nexus approach has gained significant momentum since 2011, it is however not yet widely adopted in either policy or development planning (Wicaksono et al., 2017).

Rasul and Sharma (2016) state that the nexus framework and climate change adaptation share aims and principles. Rasul (2016) suggests that one mechanism for enabling a policy framework for managing nexus challenges is to strengthen the role of the national planning commissions in the countries being assessed. This is necessary even in developed countries. Sharmina et al. (2016), for example, notes that most of the United Kingdom's land-use policies are compartmentalised, with the administration of the sectors occurring in silos.

\footnotetext{
Case Study 3:

In a WEF nexus assessment of the Mekong basin it was determined that a significant growth in the capacity and supply of power through hydropower developments could, amongst other impacts, reduce fish stocks and fish diversity, as well as the availability of water to downstream users (Smajgl et al., 2016). A policy of managing energy demand, as opposed to a focus on energy supply and capacity alone, could reduce the negative impacts of hydropower on food and water security within this large river basin. This policy intervention recommendation would probably not have been arrived at if a single-sector energy assessment, as opposed to a WEF nexus assessment, was undertaken.
} 
Schreiner and Baleta (2015) in turn report that the nexus philosophy is becoming an important component of development planning, with synergies existing across international boundaries within a region. Ololade et al. (2017) concur regarding the potential of regional cooperation, although they note that even though South Africa's policy allows for the implementation of a WEF nexus approach, this form of integrated governance does not yet exist at a national level. Individual countries will need to develop their own WEF nexus governance structures before they can engage in international endeavours in this regard.

In terms of the spatial extent of nexus governance, Artioli et al. (2017) note the rapid rate of urbanisation worldwide, and suggest that cities can play a key role in adopting the WEF nexus approach. They further state that the urbanisation of the nexus approach is part of a movement toward integrated management and that the "smart city" is the most dynamic component of that general trend (Artioli et al., 2017).

Another aspect associated with WEF nexus governance is waste. Machell et al. (2015) explain that it is possible to sustainably supply and consume more water, energy and food by addressing the mechanisms of waste. Scanlon et al. (2017) agree, noting that scarcity in these three key resources can be partially managed by reducing demands. An example of the benefit that could be derived from the processing of waste is provided in "Case Study 4".

Pandey and Shrestha (2017) conclude that the WEF security nexus is widely accepted in international development circles. (Dawoud, 2017) emphasise that the challenge is how to implement a WEF nexus framework where the risks, challenges and opportunities are identified and considered by all relevant stakeholders. As Brundtland (1987) stated over three decades ago,

\section{Case Study 4:}

Machell et al. (2015) suggest that waste is an indispensable component often neglected in WEF nexus analyses and include waste as the fourth core component in their nexus framework conceptualisation. An example of waste reclamation, presented by Walker et al. (2014) suggests that urine separation could possibly recover $47 \%$ of the nitrogen from the food consumed in London. This could potentially yield an income of $\$ 33$ million per year from fertiliser production. This practice would reduce waste, provide revenue that will contribute to water treatment costs, and provide a key resource for use within the agricultural sector.

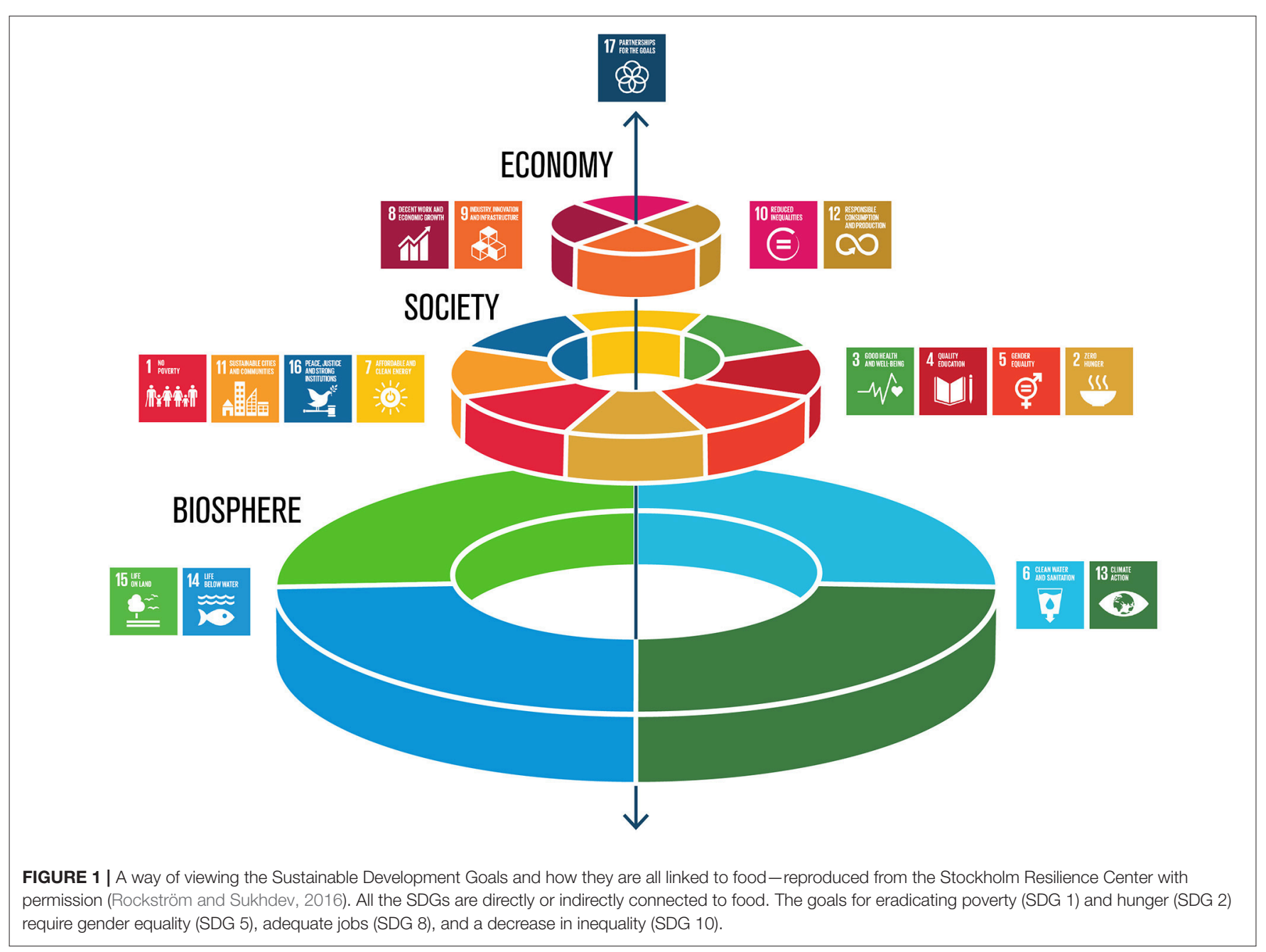


"The real world of interlocked economic and ecological systems will not change; the policies and institutions concerned must."

The WEF nexus has also become important in both the drafting and the subsequent monitoring of the SDGs (Biggs et al., 2015). It could be said that the SDGs provide a test for the nexus approach (Ringler et al., 2013). Salam et al. (2017) argue that the interconnections between the SDGs emphasise the need for a nexus approach to achieve these goals. Boas et al. (2016) suggest that the nexus approach, together with its incorporation of the SDGs, is key to understanding why it has garnered such interest within the sustainable development fraternity.

\section{CONCLUSIONS}

The WEF nexus has been widely promoted in policy and development circles since 2011. This framework has potential strengths. It however also faces challenges if it is to be widely adopted.

In terms of possible weaknesses associated with the WEF nexus, a concern identified in the literature is that livelihoods and the environment are often omitted from these assessments. WEF nexus studies have, to date, to a large degree focused on global macro-scale resource security. This was not the intention when the concept was first promoted. For this framework to gain traction, particularly in light of the SDGs, it must be utilised to achieve adequate resource security for all, thus "leaving no one behind". It must simultaneously acknowledge and protect the environment as the irreplaceable foundation of the nexus.

A multi-centric approach will add complexity, especially when interconnections, trade-offs and drivers are incorporated into the assessment. The fact that a WEF nexus approach cannot be a one-size-fits-all model means that it must be

\section{REFERENCES}

Abdullaev, I., and Rakhmatullaev, S. (2016). Setting up the agenda for water reforms in Central Asia: does the nexus approach help? Environ. Earth Sci. 75:870. doi: 10.1007/s12665-016-5409-8

Allouche, J., Middleton, C., and Gyawali, D. (2015). Technical Veil, Hidden Politics: Interrogating the Power Linkages behind the Nexus. Water Altern. 8, 610-626.

Al-Saidi, M., and Elagib, N. A. (2017). Towards understanding the integrative approach of the water, energy and food nexus. Sci. Total Environ. 574, 1131-1139. doi: 10.1016/j.scitotenv.2016. 09.046

Artioli, F., Acuto, M., and McArthur, J. (2017). The water-energy-food nexus: An integration agenda and implications for urban governance. Polit. Geogr. 61, 215-223. doi: 10.1016/j.polgeo.2017.08.009

Bazilian, M., Rogner, H., Howells, M., Hermann, S., Arent, D., Gielen, D., et al. (2011). Considering the energy, water and food nexus: towards an integrated modelling approach. Energy Policy 39, 7896-7906. doi: 10.1016/j.enpol.2011.09.039

Belinskij, A. (2015). Water-energy-food nexus within the framework of international water law. Water 7, 5396-5415. doi: 10.3390/w71 05396

Benson, D., Gain, A. K., Rouillard, J., and Giupponi, C. (2017). "Governing for the Nexus," in Water-Energy-Food Nexus: Principles and Practices, eds P. Abdul Salam, S. Shrestha, V. Prasad Pandey, and A. K. Anal (Washington, DC: John Wiley and Sons, Inc.), 77-88. scaled and/or modified (sometimes significantly) for different assessments, e.g., cities, countries, and regions, which is viewed as a weakness by some. The availability of complete, relevant data also poses a challenge to the practical implementation of the WEF nexus. The WEF nexus is a relatively new and developing framework.

While the nexus concept is not novel, novelty is not a prerequisite for relevance. If the multi-centric WEF nexus approach provides a better means of addressing the complex development and security challenges that the global community is facing than existing frameworks such as IWRM, then its potential adoption should be explored further. The WEF nexus framework is considered by many authors in both academic and grey literature as holding promise for guiding policy development and governance structures in a world that is facing climate change, population growth, and inequality in terms of access to resources. The linking of WEF nexus assessments with the SDGs is therefore imperative.

\section{AUTHOR CONTRIBUTIONS}

GS wrote the manuscript in consultation with GJ, who supervised the project.

\section{FUNDING}

This work is based on the research supported in part by the National Research Foundation of South Africa (Grant Number: 114692). GJ's academic position at the University of KwaZuluNatal was supported by Umgeni Water through the Umgeni Water Chair of Water Resources Management.
Benson, D., Gain, A. K., and Rouillard, J. J. (2015). Water governance in a comparative perspective: from IWRM to a 'Nexus' approach? Water Altern. 8, $756-773$.

BFAP (2012). Evaluating the Impact of Coal Mining on Agriculture in the Delmas, Ogies and Leandra Districts: A Focus on Maize Production. Pretoria: Bureau for Food and Agricultural Policy.

Biggs, E. M., Bruce, E., Boruff, B., Duncan, J. M. A., Horsley, J., Pauli, N., et al. (2015). Sustainable development and the water-energy-food nexus: a perspective on livelihoods. Environ. Sci. Policy 54, 389-397. doi: 10.1016/j.envsci.2015.08.002

Boas, I., Biermann, F., and Kanie, N. (2016). Cross-sectoral strategies in global sustainability governance: towards a nexus approach. Int. Environ. AgreementsPolitics Law Econ. 16, 449-464. doi: 10.1007/s10784-016-9321-1

Bogardi, J. J., Dudgeon, D., Lawford, R., Flinkerbusch, E., Meyn, A., Pahl-Wostl, C., et al. (2012). Water security for a planet under pressure: interconnected challenges of a changing world call for sustainable solutions. Curr. Opin. Environ. Sustain. 4, 35-43. doi: 10.1016/j.cosust.2011.12.002

Boulding, K. E. (1966). "The economics of the coming spaceship earth," in Environmental Quality in a Growing Economy, ed H. Jarrett (Baltimore: Resources for the Future, Johns Hopkins University Press), 3-14.

Brundtland, G. H. (1987). Our Common Future. Report of the World Commission on Environment and Development.

Cai, X., Wallington, K., Shafiee-Jood, M., and Marston, L. (2018). Understanding and managing the food-energy-water nexus - opportunities for water resources research. Adv. Water Resour. 111, 259-273. doi: 10.1016/j.advwatres.2017.11.014 
Cairns, R., and Krzywoszynska, A. (2016). Anatomy of a buzzword: the emergence of 'the water-energy-food nexus' in UK natural resource debates. Environ. Sci. Policy 64, 164-170. doi: 10.1016/j.envsci.2016.07.007

Daher, B., Mohtar, R. H., Lee, H., and Assi, A. (2017). "Modeling the water-energyfood nexus," in Water-Energy-Food Nexus: Principles and Practices, eds P. Abdul Salam, S. Shrestha, V. Prasad Pandey, and A. K. Anal (Washington, DC: John Wiley and Sons, Inc.), 55-66.

Dawoud, M. A. H. (2017). "Water, energy, and food security nexus in the west asian region," in Water-Energy-Food Nexus: Principles and Practices, eds P. Abdul Salam, S. Shrestha, V. Prasad Pandey, and A. K. Anal (Washington, DC: John Wiley and Sons, Inc.), 163-180.

de Grenade, R., House-Peters, L., Scott, C. A., Thapa, B., Mills-Novoa, M., Gerlak, A., et al. (2016). The nexus: reconsidering environmental security and adaptive capacity. Curr. Opin. Environ. Sustain. 21, 15-21. doi: 10.1016/j.cosust.2016.10.009

De Laurentiis, V., Hunt, D. V. L., and Rogers, C. D. F. (2016). Overcoming food security challenges within an energy/water/food nexus (EWFN) approach. Sustainability 8:95. doi: 10.3390/su8010095

de Loe, R. C., and Patterson, J. J. (2017). Rethinking water governance: moving beyond water-centric perspectives in a connected and changing world. Nat. Resour. J. 57, 75-99. Available online at: http://digitalrepository.unm.edu/nrj/ vol57/iss $1 / 4$

FAO (2014). The Water-Energy-Food Nexus A New Approach in Support of Food Security and Sustainable Agriculture.

Gain, A. K., Giupponi, C., and Benson, D. (2015). The water-energy-food (WEF) security nexus: the policy perspective of Bangladesh. Water Int. 40, 895-910. doi: $10.1080 / 02508060.2015 .1087616$

Gallagher, L., Dalton, J., Bréthaut, C., Allan, T., Bellfield, H., Crilly, D., Cross, K., et al. (2016). The critical role of risk in setting directions for water, food and energy policy and research. Curr. Opin. Environ. Sustain. 23, 12-16. doi: 10.1016/j.cosust.2016.10.002

Garcia, D. J., and You, F. (2016). The water-energy-food nexus and process systems engineering: a new focus. Computers Chem. Eng. 91, 49-67. doi: 10.1016/j.compchemeng.2016.03.003

Grafton, R. Q., McLindin, M., Hussey, K., Wyrwoll, P., Wichelns, D., Ringler, C., et al. (2016). Responding to global challenges in food, energy, environment and water: risks and options assessment for decision-making. Asia Pacific Policy Stud. 3, 275-299. doi: 10.1002/app5.128

Green, J. M. H., Cranston, G. R., Sutherland, W. J., Tranter, H. R., Bell, S. J., Benton, T. G., et al. (2017). Research priorities for managing the impacts and dependencies of business upon food, energy, water and the environment. Sustain. Sci. 12, 319-331. doi: 10.1007/s11625-016-0402-4

Greenpeace (2018). New Satellite Data Reveals the World's Largest Air Pollution Hotspot is Mpumalanga. Available online at: https://www.greenpeace.org/africa

Gupta, A. D. (2017). "Water-Energy-Food (WEF) Nexus and Sustainable Development," in Water-Energy-Food Nexus: Principles and Practices, eds P. Abdul Salam, S. Shrestha, V. Prasad Pandey, and A. K. Anal (Washington, DC: John Wiley and Sons, Inc.), 221-241.

Hoff, H. (2011). "Understanding the Nexus," in Background Paper for the Bonn 2011 Conference: The Water, Energy and Food Security Nexus. Stockholm: Stockholm Environment Institute.

IRENA (2015). Renewable Energy in the Water, Energy and Food Nexus. IRENA.

Kurian, M. (2017). The water-energy-food nexus: trade-offs, thresholds and transdisciplinary approaches to sustainable development. Environ. Sci. Policy 68, 97-106. doi: 10.1016/j.envsci.2016.11.006

Leck, H., Conway, D., Bradshaw, M., and Rees, J. (2015). Tracing the water-energyfood nexus: description, theory and practice. Geogr. Compass 9, 445-460. doi: 10.1111 /gec 3.12222

Leese, M., and Meisch, S. (2015). Securitising sustainability? Questioning the 'water, energy and food-security nexus.' Water Altern. 8, 695-709.

Liu, J., Mao, G., Hoekstra, A. Y., Wang, H., Wang, J., Zheng, C., et al. (2018). Managing the energy-water-food nexus for sustainable development. Appl. Ener. 210, 377-381. doi: 10.1016/j.apenergy.2017. 10.064

Liu, J., Yang, H., Cudennec, C., Gain, A. K., Hoff, H., Lawford, R., et al. (2017). Challenges in operationalizing the water-energy-food nexus. Hydrol. Sci. J. 62, 1714--1720. doi: 10.1080/02626667.2017.1353695
Machell, J., Prior, K., Allan, R., and Andresen, J. M. (2015). The water energy food nexus - challenges and emerging solutions. Environ. Sci. 1, 15-16. doi: 10.1039/C4EW90001D

McCarthy, T. S. (2011). The impact of acid mine drainage in South Africa. South Afr. J. Sci. 107:712. doi: 10.4102/sajs.v107i5/6.712

Meadows, D., Randers, J., and Meadows, D. (2004). The Limits to Growth: The 30-Year Update. London: Earthscan.

Meadows, D. H., Meadows, D. L., Randers, J., and Behrens, W. W. III. (1972). The limits to growth. South. Afr. J. Sci. 211, 1-205.

Mohtar, R. H., and Daher, B. (2012). "Water, energy, and food: the ultimate nexus," in Encyclopedia of Agricultural, Food, and Biological Engineering, 2nd Edn, eds D. R. Heldman and C. I. Moraru (Taylor \& Francis). doi: 10.1081/E-EAFE2-120048376

Muir, J. (1911). My First Summer in the Sierra. John Muir Writings.

Muller, M. (2015). The 'Nexus' as a step back towards a more coherent water resource management paradigm. Water Altern. 8, 675-694.

NIC (2012). Global Trends 2030: Alternative Worlds. New York, NY: NIC.

Ololade, O. O., Esterhuyse, S., and Levine, A. D. (2017). "The water-energyfood nexus from a south african perspective," in Water-Energy-Food Nexus: Principles and Practices, eds P. Abdul Salam, S. Shrestha, V. Prasad Pandey, and A. K. Anal (Washington, DC: John Wiley and Sons, Inc.).

Owen, A., Scott, K., and Barrett, J. (2018). Identifying critical supply chains and final products: An input-output approach to exploring the energywater-food nexus. Appl. Energy 210, 632-642. doi: 10.1016/j.apenergy.2017. 09.069

Pahl-Wostl, C. (2017). Governance of the water-energy-food security nexus: a multi-level coordination challenge. Environ. Sci. Policy. 92, 356-67. doi: 10.1016/j.envsci.2017.07.017

Pandey, V. P., and Shrestha, S. (2017). "Evolution of the nexus as a policy and development discourse," in Water-Energy-Food Nexus: Principles and Practices, eds P. Abdul Salam, S. Shrestha, V. Prasad Pandey, and A. K. Anal (Washington, DC: John Wiley and Sons, Inc), 11-20.

Rasul, G. (2016). Managing the food, water, and energy nexus for achieving the sustainable development goals in South Asia. Environ. Dev. 18, 14-25. doi: 10.1016/j.envdev.2015.12.001

Rasul, G., and Sharma, B. (2016). The nexus approach to water-energy-food security: an option for adaptation to climate change. Climate Policy 16, 682-702. doi: 10.1080/14693062.2015.1029865

Ringler, C., Bhaduri, A., and Lawford, R. (2013). The nexus across water, energy, land and food (WELF): potential for improved resource use efficiency? Cur. Opin. Environ. Sustain. 5, 617-624. doi: 10.1016/j.cosust.2013. 11.002

Rockstrom, J., Steffen, W., Noone, K., Persson, A., I. I. I., Chapin, F. S., et al. (2009). Planetary boundaries: exploring the safe operating space for humanity. Ecol. Soc. 14:32. doi: 10.5751/ES-03180-140232

Rockström, J., and Sukhdev, P. (2016). How Food Connects All the SDGs. Stockholm Resilience Centre.

Sachs, J. D. (2015). The Age of Sustainable Development. New York, NY: Columbia University Press.

Salam, P. A., Pandey, V. P., Shrestha, S., and Anal, A. K. (2017). “The need for the nexus approach," in Water-Energy-Food Nexus: Principles and Practices, eds P. Abdul Salam, S. Shrestha, V. Prasad Pandey, and A. K. Anal (Washington, DC: John Wiley and Sons, Inc), 1-10.

Scanlon, B. R., Ruddell, B. L., Reed, P. M., Hook, R. I., Zheng, C. M., Tidwell, V. C., et al. (2017). The food-energy-water nexus: transforming science for society. Water Resour. Res. 53, 3550-3556. doi: 10.1002/2017WR 020889

Schreiner, B., and Baleta, H. (2015). Broadening the Lens: A Regional Perspective on Water, Food and Energy Integration in SADC. Aqua Proc. 5, 90-103. doi: 10.1016/j.aqpro.2015.10.011

Sharmina, M., Hoolohan, C., Bows-Larkin, A., Burgess, P. J., Colwill, J., Gilbert, P., et al. (2016). A nexus perspective on competing land demands: wider lessons from a UK policy case study. Environ. Sci. Policy 59, 74-84. doi: 10.1016/j.envsci.2016.02.008

Siciliano, G., Rulli, M. C., and D'Odorico, P. (2017). European large-scale farmland investments and the land-water-energy-food nexus. Adv. Water Resour. 110, 579-590. doi: 10.1016/j.advwatres.2017.08.012 
Simpson, G., and Berchner, M. (2017). Measuring integration - towards a waterenergy-food nexus index. Water Wheel 16, 22-23.

Smajgl, A., Ward, J., and Pluschke, L. (2016). The water-food-energy Nexus - Realising a new paradigm. J. Hydrol. 533, 533-540. doi: 10.1016/j.jhydrol.2015.12.033

Spiegelberg, M., Baltazar, D. E., Sarigumba, M. P. E., Orencio, P. M., Hoshino, S., Hashimoto, S., et al. (2017). Unfolding livelihood aspects of the water-energy-food nexus in the dampalit watershed, Philippines. J. Hydrol. 11, 53-68. doi: 10.1016/j.ejrh.2015. 10.009

Walker, V. R., Beck, M. B., Hall, J. W., Dawson, R. J., and Heidrich, O. (2014). The energy-water-food nexus: Strategic analysis of technologies for transforming the urban metabolism. J. Environ. Manage. 141, 104-115. doi: 10.1016/j.jenvman.2014.01.054

WEF (2011). Water Security: The Water-Energy-Food-Climate Nexus. World Economic Forum Initiative.

Wicaksono, A., Jeong, G., and Kang, D. (2017). Water, energy, and food nexus: review of global implementation and simulation model development. Water Policy 19, 440-462. doi: 10.2166/wp. 2017.214
Wichelns, D. (2017). The water-energy-food nexus: Is the increasing attention warranted, from either a research or policy perspective? Environ. Sci. Policy 69, 113-123. doi: 10.1016/j.envsci.2016.12.018

WWF and SABMiller (2014). The Water-Food-Energy Nexus: Insights into Resilient Development. Available online at: http://assets.wwf.org.uk/downloads/sab03 01_sab_wwf_project_nexus_final.pdf

Conflict of Interest Statement: GS is employed by company Jones \& Wagener (Pty) Ltd.

The remaining author declares that the research was conducted in the absence of any commercial or financial relationships that could be construed as a potential conflict of interest.

Copyright (c) 2019 Simpson and Jewitt. This is an open-access article distributed under the terms of the Creative Commons Attribution License (CC BY). The use, distribution or reproduction in other forums is permitted, provided the original author(s) and the copyright owner(s) are credited and that the original publication in this journal is cited, in accordance with accepted academic practice. No use, distribution or reproduction is permitted which does not comply with these terms. 